Short Communication

\title{
Remediation of chromium contaminated soil by microbial electrochemical technology
}

\author{
Guan-Xi Li ${ }^{1,2}$ He-Chuan Yang ${ }^{2}$, Shuai Guo ${ }^{1}$, Chao-Fan Qi ${ }^{1}$, Ke-Jing Wu ${ }^{1}$ and Fen-Fen Guo ${ }^{1 *}$ \\ ${ }^{1}$ School of Life Sciences, Qufu Normal University, Shandong 273165, China \\ ${ }^{2}$ Lianyungang Academy of Agricultural Sciences, Lianyungang, Jiangsu 222006, China \\ "E-mail: guoff@qfnu.edu.cn
}

doi: $10.20964 / 2020.07 .44$

Received: 17 February 2020 / Accepted: 5 April 2020 / Published: 10 June 2020

Soil is an irreplaceable resource for human survival and development. With the development of the heavy metal industry, heavy metal pollution of soil has become a serious problem that human beings are facing, especially soil pollution caused by hexavalent chromium. In this study, a plant microbial fuel cell (PMFC) system for the remediation of hexavalent chromium-contaminated soil was constructed by coupling plants and microbial fuel cells (MFCs). The removal efficiency of hexavalent chromium and the power generation capacity of the system were investigated. In this study, a new single-chamber PMFC was constructed, which was activated by Lycoris radiata and Lycoris sprengeri. Then, by controlling the HRT, open-circuit or closed-circuit conditions and the initial concentration of hexavalent chromium in the soil, the effects of these factors on the chromium removal efficiency of the PMFC system were analysed.

Keywords: Soil pollution; Phytoremediation; Plant microbial fuel cell; Hexavalent chromium; Lycoris

\section{$\underline{\text { FULL TEXT }}$}

(C) 2020 The Authors. Published by ESG (www.electrochemsci.org). This article is an open access article distributed under the terms and conditions of the Creative Commons Attribution license (http://creativecommons.org/licenses/by/4.0/). 